\title{
EDITORIAL
}

\section{Strategic protection of Asian rhinos: the conservation success of the greater one-horned rhinoceros}

\author{
Arup Kumar Hazarika ${ }^{{ }^{*}}$, Unmilan Kalita ${ }^{2}$, Chittaranjan Baruah \\ ${ }^{1}$ Department of Zoology, Cotton University, Guwahati, India \\ ${ }^{2}$ Department of Economics, Barnagar College, Sorbhog, India \\ ${ }^{3}$ Postgraduate Department of Zoology, Darrang College, Tezpur, Assam, India
}

An environment with resounding species diversity reinforces economic stability and human livelihoods over time (UNEP, 2008). This comes from the fact that the environment generates substantial scientific, ecological, cultural and spiritual dividends to the societies they are a part of (Abbot and Neba, 2001). As such, existence and survival of the rhinoceros directly or indirectly assists other wildlife and people who depend on the health of that environment (Brook et al., 2014). At the dawn of the twentieth century, 500,000 rhinos roamed Africa and Asia (Shelley, 2018). These numbers dropped to 70,000 by 1970 , and today, a little over 27,000 rhinos remain in the wild. Due to continuous hunting and habitat degradation over decades, few few rhinos have survived outside national parks and reserves (Gustafson et al., 2018). Three of the five rhino species that have survived are from Asia: the greater one-horned rhino or Indian rhinoceros (Rhinoceros unicornis), which has an estimated 3,500 individuals, the Javan rhinos (Rhinoceros sondaicus), which has fewer than 70 individuals, and the Sumatran rhinos (Dicerorhinus sumatrensis), which has fewer than 80 individuals. The Javan and Sumatran are now classified as critically endangered (CR) species on the IUCN Red List. These rhinos, which are now located in Indonesia, continue to suffer a variety of threats. Surprisingly, the Indian rhinoceros was downlisted from endangered (EN) to vulnerable (VU) category in 2008 owing to its improved condition. Following substantial population gains, the larger one-horned rhino has become one of Asia's greatest conservation success stories (GhoshHarihar et al., 2019). The species is still threatened, however, by poaching for its horn and habitat loss and degradation.

Consumer demand for rhino horn, particularly in Asia, promotes poaching. In 2015, poachers murdered at least 1,300 rhinos in Africa. 691 rhinos were poached in 2017. In 2018, 508 rhinos were poached, a modest decrease. Stopping this is vital for their protection, especially for Asian indigenous species. Poaching will continue to be a big threat to rhinos. Preventive measures must be strengthened. The ability to detect illegal wildlife traffickers' movements is important to their capture (Soud and Talukdar, 2013).

Only 67 Javan rhinos are believed to exist in the wild, making it one of the most endangered big mammals. They are exclusively found in Ujung Kulon National Park in Java's extreme southwest. The WWF supports the Ujung Kulon Rhino Protection Units to protect the surviving Javan rhino population from poaching and environmental deterioration. In 2011, Vietnam declared a rhino subspecies extinct (Brook et al., 2014). As part of this effort, the WWF is clearing Arenga palm trees from 6,178 acres of historic habitat. Removing palm trees and aggressively restoring natural flora and food plants is vital for rhino survival. Data on Javan rhino activity, distribution, mobility, population size and genetic diversity are being collected using video traps (Haryono et al., 2015).

A total of less than 80 individuals survive in dispersed subpopulations across Indonesia's Sumatra and Borneo islands. The Javan rhino population is tiny, but it is a robust reproductive population. However, the Sumatran rhino is a rare species found only on the Indonesian islands of Sumatra and Kalimantan (Havmller et al., 2016). The few survivors live in scattered woodlands, making breeding difficult. Sumatran rhinos, the world's tiniest rhinoceros, cannot breed in the wild. As a result, their population has decreased.

Native to the Indian subcontinent, the Indian rhinoceros thrives majorly in the alluvial Terai-Duar savanna, grasslands and river forests of the Kaziranga National Park and Pobitora Wildlife Sanctuary in the Indian state of Assam, and Chitwan National Park of Nepal. Exotic species, natural succession, and changes in water regimes are the primary threats to its habitat. The Indian and Nepalese governments have helped conserve this species. Reintroduction efforts have been made in India's designated rhino Protected Areas, notably Kaziranga. India passed a species-preservation law, which helped. However, approximately $70 \%$ of the Indian rhino population is limited to Kaziranga National Park. Land-use changes in the plateau, Pesticide run-off, civil unrest, increased poaching, and habitat degradation all threaten the Indian rhino's current state. This begs us to understand why and how conservation efforts in the Kaziranga led to conservation success of the greater one -horned rhinoceros in the Indian subcontinent.Kaziranga National Park (KNP) is "the largest pristine and representative section in the Brahmaputra floodplain" (UNESCO, 1985). It has 2,413 rhinos (KNP Rhino Census, 2018), 2/3 of the global population. A natural World Heritage Site in India. KNP has been in the forefront of India's environmental conservation efforts for decades due to river bank erosion, sedimentation, and land creation/destruction (Hazarika and Kalita, 2019).

To combat poaching, the Indian government has undertaken many conservation measures. The Indian Wildlife (Protection) Act, 1972, and the Indian Forest Act, 1927, safeguard KNP. It also protected forest 
personnel from prosecution under Section 197 (2) of the 1973 Criminal Procedure Code (Singh, 2017). Wildlife (Protection) Act currently carries a minimum seven year sentence and a 50,000 rupee fine. A tiger reserve since 2007, KNP The Indian NTCA financed the Electronic Eye monitoring equipment in Kaziranga as part of "Project Tiger." The project featured seven tall towers with cameras for 24/7 real-time video access from the control centre. Authorities think poachers are well-armed and seeking for opportunities (Anon., 2017). These projects have acquired 12 rhinos since 2015. 2401-2413 (2017). This project would increase communication between anti-poaching camps in Kaziranga National Park. These groups promoted public awareness regarding wildlife and climate change. To create Indian Rhino Vision 2020, the International Rhino Foundation partnered with WWF, Bodoland Territorial Council, and USFWS. These areas are included in IRV 2020. Despite several challenges, the Assam Forest Department successfully reintroduced 20 rhinos into Manas National Park. Helvetica helped the state's rhino population reach 3000 by 2020 .

Local communities have been involved in conservation efforts to educate local youth about rhino preservation, conservation, and relocation (Hazarika and Kalita, 2019). Any conservation effort must include indigenous children and give them hope for the future. Community conservation groups assist monitor and police KNP, improving environmental knowledge and local revenue (Barbora, 2017). Agriculture, handicrafts, and ecotourism all rose in popularity. State, ATC, WWF, and other NGOs aided community-based conservation organisations. Conservation of rhinos in Manas National Park has been promoted by Maozigendri Ecotourism and Ever Welfare Societies (Dutt, 2019). 18 community organisations form the United Front for Conservation of Nature to boost animal conservation in the Manas National Park. Translocating rhinos is vital to rhino conservation. It improves genetic variety, reduces disease and inbreeding risks, and revitalises habitats (Lahkar et al., 2011). The Asian elephant, tigers, swamp deer, and rare endemics like the hispid-hare and Pygmy-hog depend on unhealthy grasslands. A healthy park and its visitors help the locals.

The Indian Ministry of Environment, Forest and Climate Change established a National Conservation Strategy for Rhinos in 2019. As the first of its kind for the species in India, this project attempts to conserve it through five objectives: better protection; broader distribution; research and monitoring; and trans-boundary collaboration and funding. Officials from India, Bhutan, Indonesia, Malaysia, and Nepal signed the New Delhi Declaration on Asian Rhinos 2019 to increase the population of three Asian rhino species. As part of the declaration, the rhino range states committed to perform a four-year evaluation of the population of the three Asian rhino species to determine the need for coordinated action. The event is being organized by the Ministry of Environment, Forests and Climate Change, WWF-India, and Aaranyak. The Indian government has pledged to save the onehorned Rhino and two other severely endangered Rhinos. A conservation status report on Asian rhinos and the larger one-horned rhinoceros on the Indian subcontinent. Remember that one of the main cornerstones of conservation is local community participation.

\section{REFERENCES}

Abbot J. and Neba D. 2001. Understanding the links between conservation and development in the Bamenda Highlands, Cameroon. World Development 29:1115-1136.
Anonymous. 2017. The decrease in rhino poaching in Kaziranga National Park. Available at https:// www.kaziranga-national-park.com/blog/decreaseinrhino-poaching-kaziranga-national-park/.

Barbora S. 2017. Riding the rhino: Conservation, conflicts, and militarisation of Kaziranga National Park in Assam. Antipode, 49(5), 1145-1163.

Brook S.M., Dudley N., Mahood, S.P., Polet G., Williams A.C., Duckworth J.W. and Long B. 2014. Lessons learned from the loss of a flagship: The extinction of the Javan rhinoceros Rhinoceros sondaicus annamiticus from Vietnam. Biological Conservation, 174, 2129.

Dutt B. 2019. Rewilding: India's Experiments in Saving Nature. Oxford University Press.

Ghosh-Harihar M., An R., Athreya R., Borthakur U., Chanchani P., Chetry D. and Price, T. D. 2019. Protected areas and biodiversity conservation in India. Biological Conservation, 237, 114-124.

Gustafson K., Sandstrom T. and Townsend, L. 2018. The bush war to save the rhino: Improving counterpoaching through intelligence. Small Wars \& Insurgencies, 29(2), 269-290.

Haryono M., Rahmat U., Daryan M., Raharja A., Muhtarom A., Firdaus A. and Khairani, K. 2015. Monitoring of the Javan rhino population in Ujung Kulon National Park, Java. Pachyderm, 56, 82-86.

Havmøller R.G., Payne J., Ramono W., Ellis S., Yoganand K., Long B. and Burgess N. 2016. Will current conservation responses save the critically endangered Sumatran rhinoceros Dicerorhinus sumatrensis?. Oryx, 50 (2), 355-359.

Hazarika A.K., and Kalita U. 2019. Conservation and Livelihood Conflict of Kaziranga National Park: A World Heritage Site of Assam, India. Space and Culture, India, 7(3), 224-232.

Lahkar B., Talukdar B. and Sarma P. 2011. Invasive species in grassland habitat: an ecological threat to the greater one-horned rhino (Rhinoceros unicornis). Pachyderm, 49, 33-39.

Mazoomdaar J. 2018. How poaching was curbed in Kaziranga, and what it would take to step up conservation. The Indian Express, Available at https:// indianexpress.com/article/explained/kaziranga-rhinoceros census-2018-how-poaching-was-curbed-and-what-itwou ld-take-to-step-up-conservation-5119865/.

Rhino Census. 2018. Government of India in association with the Forest officials of KNP. Available at http:// www.indiaenvironmentportal.org.in/content/25228/ rhino-census/.

Shelley L.I. 2018. The Tragic Trajectory of the Rhino Horn Trade. In Dark Commerce (pp. 87-110). Princeton University Press.

Singh S. 2017. Protection measures considerably increase population of one-horned rhino. Press Information Bureau, Government of India; Special Service and Features. Available at http://pib.nic.in/newsite/print release. aspx?relid $=158080$.

Soud R., Talukdar S. 2013. Contemporary crisis of rhinoceros in Assam: a critical review. Asian Journal of Conservation Biology 2 (1): 82-83.

UNEP. 2008. Protected areas in today's world: their values and benefits for the welfare of the planet. CBD Technical Series, no. 36. Secretariat of the Convention on Biological Diversity, United Nations Environment Programme, Nairobi.

UNESCO. 1985. Kaziranga National Park: inscription of KNP as World Heritage Site by UNESCO in 1985 and related description. Available at https:// whc.unesco.org/en/list/337/.

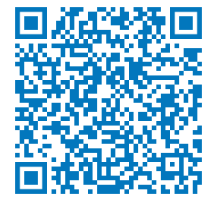

